\title{
Editorial
}

\section{Myth of Wearing White Coat}

\section{S.M. Fazlul Karim}

Vice Principal and Professor \& Head of the department of Biochemistry, Delta Medical College, Dhaka, Bangladesh and Editor-in-Chief 'Delta Medical College Journal'.

Doctors adopted to wear white coat (apron) since the 1800 s to restore credibility to a profession and it is also worn by the bioscientists. 1 This white coat has served as the pre eminent symbol of physicians. It is the symbol of the 'whiteness', 'cleanliness', 'pureness' or 'holiness' reflected in the garb of physicians and interestingly nurses. Western and European society has carried this symbol of whiteness to the marriage alter where brides traditionally wear white as a symbol of their purity. In the 20th century, the white coat continued as the symbol of medical authority and respect as advance upon advance firmly established the patient-doctor relationship as a beneficial encounter. ${ }^{2}$ At the turn of the 19th century the black habits of the religious nursing orders became white. In fact to this day nurses in England are called sisters (also in Bangladesh), because of their religious origin. ${ }^{2}$

The White Coat Ceremony, as envisioned by Dr. Gold, welcomes those embarking on their medical carriers to the community of physicians by giving them this powerful symbol of compassion and honor. Medical students beginning their studies in medical school/colleges, see their education and role as future doctors as aspiring to be worthy of the long white coat (apron). The white coat symbolizes a standard of professionalism and caring and emblem of the trust they must earn from patient. 1 3 At virtually every medical college, the first symbolic act is the "White Coat Ceremony" originated by Arnold. P. Gold, is also in practice in our country.

One may be surprised to know that prior to late 19th century doctors wore not white but black garb. At that time seeking medical advice was usually a last resort for people and frequently a precursor to death. The converse, of course, is evil or death depicted in black. ${ }^{2}$
Remarkably, the progression of white coat was documented in Eakins' 1889 operating theater masterpiece entitled "The Agnew Clinic" from the University of Pennsylvania. Dr. Hayes Agnew, was seen in a white smock, with assistants wearing white, patient swathed in white sheets and the nurse had a white cap, suggesting that a new sense of cleanliness pervaded the environment. Hospitals were becoming places of healing rather than places that people went to die and the white coat symbolize this. 2,3

Now question arises, whether this white coat is necessary/compulsory to wear or not. Not all doctors wear white coat. Today pediatricians \& psychiatrists eschew it in order to reduce anxiety on the part of their patients. The term "White Coat Syndrome" is said to describe unrepresentative high blood pressure due to a patient's anxiety upon seeing a doctor in a white coat. Patients in Denmark and England do not expect their physicians to wear white coat but those in Sweden, Finland and Norway do. Studies show that younger patients prefer a doctor not to wear white, while older patients prefer the opposite. 2,3

Many studies suggest that large proportion of health care workers' white coats, particularly their cuffs and pockets were found to be highly contaminated with pathogenic and resistant bacteria like staphylococcus aureus including MRSA (Methicillin Resistant Staphylococcus aureus). Therefore white coats may be an important vector for patient-to-patient transmission of infection. Further studies suggest choosing alternative to white coats as protective gowns as the white coats are potential abodes for mites and might facilitate transmission of these organisms. ${ }^{4-6}$ 
The white coat was phased out in many hospitals in the UK in 2007, and a few years before of that it was banned in Scotland. Some hospitals have already adopted a white coat having shortened sleeves lopped off to comply with the bare below the elbow - BBE policy.1,4,6 There is mandatory dress code for doctors in some hospitals - short sleeved tunic and trousers in dark blue. The tunic has the trust logo and the word 'Doctor' on the front, and a silver pinstripe for its 'antibacterial properties'. The uniform is mandatory for junior grades: a version for consultants is available, but is not compulsory. 1,7 In Bangladesh as well as in Asian sub continent medical students feel very proud to wear apron after admission in the medical colleges. Therefore, at the entry point a medical student can't imagine himself/herself without a white coat. It is also the joyous memory of every medical student in the beginning point of their medical career.

As a medical professional my opinion is that doctors and students who are not involved in patient caring system as well as those who are not involved in laboratory work exposed to biohazards may wear white coat either long sleeve or short sleeve having name plate in the front in their work place for preservation and continuance the existence of this historical eminent traditional attire. The doctors and the students involved in patient caring system and laboratory personnel exposed to biohazards should wear dress specified by their own hospital authority in their work place. They should not wear this specific dress outside their work place.

The non medical personnel including administrators, officials, clerks, MLSS, etc, in medical institution not involved either in patient caring system or laboratory services should wear their usual dress.

\section{References}

1. Ellis O. The Return of the White Coat. BMJ Careers [Internet]. 2010 Sept [cited 2014 Feb 25]. Available from: http://careers. bmj.com/careers/ advice/ viewarticle.html? id=20001364.

2. Hochberg MS. History of Medicine the Doctor's White Coat - An Historical Perspective. Virtual Mentor. 2007;9(4):310-14.

3. Lewis LD. White Coat Ceremony Keynote Address. Speech presented at: Columbia University College of Physicians and Surgeons; August 26, 1994: New York.

4. Hill S. Wearing White Coats and Sitting on Beds: Why should it Matter? Clinical Medicine. 2011;11(6):548-53.

5. Treakle AM, Thom KA, Furuno JP, Strauss SM, Harris AD, Perencevich EN. Bacterial Contamination of Health Care Workers' White Coats. Am J Infect Control. 2009;37(2):102-105.

6. Department of Health, NHS [Internet]. Uniforms and Work Wear: An Evidence Base for Developing Local Policy. 2007 Sept [cited 2014 Feb 25]. Available from: http://webarchive .nationalarchives. gov.uk/+/www.dh.gov.uk/en/publicationsandstatisti cs/publications/publicationspolicyandguidance/dh 078433

7. Department of Health, NHS [Internet]. Uniform and Work Wear: Guidance on Uniform and Work Wear Policies for NHS Employers. 2010 March [cited 2014 Feb 25]. Available from: http:// www.ncuh.nhs. uk/about-us/freedom-of-information/disclosure$\log /$ requests/infection -control/000771-09.pdf. 